\title{
W. A. MOZART
}

\section{SIX ARIAS FROM THE OPERAS}

\section{Published Separately}

IF YOU WILL PROMISE

(Vedrai Carino)

Zerlina's Aria from Don Giovanni.

AH, 'TIS GONE FOR EVER

(Ach, ich Fühl's)

Pamina's Aria from The Magic Flute.

O LOVELINESS BEYOND COMPARE

(Dies Bildnis ist bezaubernd schön)

Tamino's Aria from The Magic Flute.

WITHIN THESE TEMPLE WALLS

(In diesen heil'gen Hallen)

Sarastro's Aria from The Magic Flute.

GOD OF LOVE

(Porgi Amor)

The Countess's Aria from The Marriage of Figaro.

THEN COME MY HEART'S DELIGHT (Deh Vieni)

Susanna's Aria from The Marriage of Figaro.

English Versions by

EDWARD J. DENT

Each 2s 6d net.

\section{BOOSEY \& HAWKES}

295 REGENT STREET, LONDON W. I 


\section{INTERNATIONAL}

\section{CELEBRITY CONCERTS}

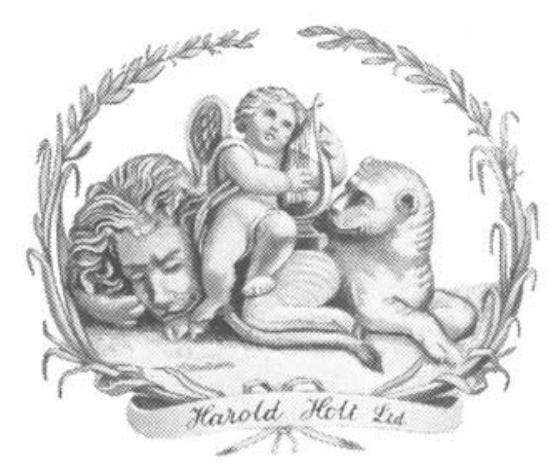

The Concert Hall Mark

of Quality in

Living Music

\section{DIRECTION HAROLD HOLT LTD}

